\title{
Effect of Processing on Nutritional Quality and Antioxidant Potentials of Leafy Vegetables
}

\author{
Saranya $\mathbf{R}^{1}$, Devanesan $\mathbf{G}^{1}$, Ramesh $\mathbf{S}^{1}$ and Gopi $\mathbf{R}^{2 *}$
}

${ }^{1}$ Department of Chemical Engineering, Faculty of Engineering, Annamalai University, Tamil Nadu, India

${ }^{2}$ Department of Botany, Faculty of Science, Annamalai University, Tamil Nadu, India

\begin{abstract}
Blanching is a primary step in processing of Green Leafy Vegetables. Despite of its preserving advantage, it leads to partial destruction of some nutrients like vitamin $\mathrm{C}$ which is heat liable and sensitive to light, oxygen and oxidizing agents. The study was carried out to identify a suitable blanching temperature, time and chemical media for the green leafy vegetables namely, Alternanthera sessilis, Cardiospermum helicacabum and Celosia argentea that ensures enzyme inactivation and maximum nutrient retention. The leaves were processed by the following methods (i) Blanched at $80^{\circ} \mathrm{C}, 90^{\circ} \mathrm{C}$ and $100^{\circ} \mathrm{C}$ for 5 min in distilled water (ii) Blanched in water containing chemical media (potassium metabisulphite (KMS), sodium bicarbonate and sodium chloride) at $80^{\circ} \mathrm{C}$ for the $1 \mathrm{~min}, 2 \mathrm{~min}$ and $4 \mathrm{~min}$ respectively. Blanching time and temperature increased, there is a reduction in the retention of Vitamin $C$ in all the greens. The statistical analysis $(P \leq 0.05)$ showed significant retention of vitamin $C$ on blanching the leaves at $80^{\circ} \mathrm{C}$ for $1 \mathrm{~min}$ in potassium metabisulphite. Reduction in the moisture content, fiber, Iron was also found to be statistically significant. Blanching at $80^{\circ} \mathrm{C}$ for $1 \mathrm{~min}$ in potassium metabisulphite was sufficient to inactivate peroxidase in leafy vegetables. The antioxidant properties of the fresh and blanched green leafy vegetables were subsequently determined. The study revealed the presence of phenolics (gallic acid equivalents $3.89-8.55 \mathrm{mg} / \mathrm{g}$ ), flavonoids (quercetin equivalents $9.47-37.66 \mathrm{mg} / \mathrm{g}$ ) and tannins (tannic acid equivalents $10.47-13.58 \mathrm{mg} / \mathrm{g}$ ). Three of the samples were exhibited remarkable DPPH radical scavenging activities $(>70 \%)$ with significant IC ${ }_{50}$ values of 653.10 and $760.34 \mu \mathrm{g} / \mathrm{ml}$ respectively. The result showed that blanching at $80^{\circ} \mathrm{C}$ for $1 \mathrm{~min}$ with potassium metabisulphite as a chemical media had a good retention of Vitamin $\mathrm{C}$ and least effect on other nutritional content. Hence it is found that blanching is the best method of preserving GLV without compromising its nutritional quality and antioxidant potentials.
\end{abstract}

Keywords: Green leafy vegetables; Blanching; Antioxidant activity; Vitamin C; Nutritional quality

\section{Introduction}

Green Leafy Vegetables (GLVs) are the most nutritious agricultural products and are widely and preferably consumed in fresh. They are rich sources of calcium, iron, $\beta$-carotene, Vitamin $C$, dietary fiber and many trace elements. India is blessed with an array of leafy vegetables of which some are cultivated many are gathered [1]. Fruits and vegetables contain different antioxidant compounds such as Vitamin $\mathrm{C}$, vitamin $\mathrm{E}$ and carotenoids, whose activities have been established in recent years. Flavonoids, tannins and other phenolic constituents present in food of plant origin are also potential antioxidants $[2,3]$. The potentially cancer inducing oxidative damage might be prevented or limited by dietary antioxidants found in fruits and vegetables. Studies to date have demonstrated that phytochemicals in common fruits and vegetables can have complementary and overlapping mechanisms of action, including scavenging of oxidative agents, stimulation of the immune system, regulation of gene expression in cell proliferation and apoptosis, hormone metabolism, antibacterial and antiviral effects [4]. Imbalance of oxidizing agents and natural antioxidants in the body results in oxidative stress and triggers pathogenic advancement of some severe diseases such as, atherosclerosis, liver cirrhosis, cataracts, cardiovascular, cancer, neurodegenerative disorders and diabetes [5].

Green leafy vegetables are generally consumed in the cooked form apart from the salads. Therefore, there is a need to assess the changes that occur in the antioxidant activity on cooking. Few works have reported the effect of cooking on antioxidant activity of vegetables. Blanching the Nigerian GLV reduces their antioxidant properties drastically [6]. The uncooked GLV had significantly higher values of TBARS when compared to the cooked vegetables [7]. Some evidences showed that Generation of oxygen radicals, such as superoxide radical $\left(\mathrm{O}_{2}^{-1}\right)$, hydroxyl radical $\left(\mathrm{OH}^{-}\right)$and non-free radical species, such as $\mathrm{H}_{2} \mathrm{O}_{2}$ and singlet oxygen $\left(\mathrm{O}_{2}^{-1}\right)$ are associated with cellular and metabolic injury and accelerating aging, cancer, cardiovascular diseases, neurodegenerative diseases and inflammation [8,9]. Natural antioxidants like $\alpha$-tocopherol and synthetic antioxidants such as butylated hydroxyanisole (BHA), butylated hydroxytoluene, tert-butyl hydroquinone and propyl gallate are widely used as food preservatives. But the use of these synthetic antioxidants is increasingly getting limited because of their toxicity and detrimental effects on health [10]. It is the largest producer of fruits and vegetables in world. It is estimated that India processes less than $1 \%$ of production and about $30 \%$ to $35 \%$ production cannot be utilized due to lack of adequate technology for processing, handling, storage and processing infrastructure [11].

Blanching is a primary step in processing of vegetables. It stops the enzyme action, sets the colour and shortens the drying and dehydration time. This technique is used by indigenous people to reduce or eliminate the bitterness of the vegetables and acid components that are common on leaves [12]. More than $90 \%$ of the vitamin C in human diets are supplied by fruits and vegetables. But vitamin $\mathrm{C}$ is most difficult of the vitamin to preserve during blanching and dehydration [13]. Controlled blanching can contribute to retention of vitamins and nutrients in

*Corresponding author: Gopi R, Department of Botany, Faculty of Science Annamalai University, Annamalai Nagar-608 002, Tamil Nadu, India, Tel: +91 9952362027; E-mail: saranyaranganathan21@gmail.com

Received August 16, 2017; Accepted September 06, 2017; Published September 14,2017

Citation: Saranya R, Devanesan G , Ramesh S, Gopi R (2017) Effect of Processing on Nutritional Quality and Antioxidant Potentials of Leafy Vegetables. J Food Process Technol 8: 694. doi: 10.4172/2157-7110.1000694

Copyright: (c) 2017 Saranya R, et al. This is an open-access article distributed under the terms of the Creative Commons Attribution License, which permits unrestricted use, distribution, and reproduction in any medium, provided the original author and source are credited. 
processed foods $[14,15]$. Peroxidase is one of the most heat stable enzymes and is often used as an index of blanching [16]. Peroxidase inactivation is faster at higher temperature [17].

The present study aims at drawing a comparative sketch of some green leafy vegetables and the effect of blanching on nutritional value and antioxidant potentials of selected widely consumed in Tamil Nadu and other parts of India.

\section{Materials and Methods}

\section{Plant materials}

The leafy vegetables were procured from local vegetable market such as Alternanthera sessilis (L) Family: Amaranthaceae (local name: Ponnagani), Celosia argentea(L) Family: Amaranthaceae (local name: Pannai Keerai), Cardiospermum helicacabum(L) Family: Sapindaceae (local name: modikkottan) at Chidambaram, Tamil Nadu. Plants were identified and the voucher specimens and plants were kept preserved in the herbarium collections of the Department of Botany, Annamalai University and Food Processing Laboratory, Department of Chemical Engineering, Annamalai University. The leaves were separated in edible portions and washed under running water to remove the adhering mud particles and drained completely.

\section{Blanching}

Washed leaves were processed by the following methods: (i) Blanched at $80^{\circ} \mathrm{C}, 90^{\circ} \mathrm{C}$ and $98^{\circ} \mathrm{C}$ for $5 \mathrm{~min}$ in water, (ii) Blanched in a) water containing potassium metabisulphite (KMS) $(5 \mathrm{~g} / \mathrm{L}), \mathrm{b})$ water containing sodium bicarbonate $(1 \mathrm{~g} / \mathrm{L})$ and $\mathrm{c})$ water containing Sodium chloride $(20 \mathrm{~g} / \mathrm{L})$ at $80^{\circ} \mathrm{C}$ for $1 \mathrm{~min}, 2 \mathrm{~min}$ and $4 \mathrm{~min}$ respectively. The time required for blanching was judged by residual peroxidase activity.

\section{Analysis}

The fresh green leafy vegetables and blanched green leafy vegetables were analyzed for the following components to study the effect of blanching. Moisture content was determined by standard method of AOAC [18]. Protein was estimated by Lowry et al. [19] and Fiber was determined by AOAC method [20]. The blanched samples are tested for peroxidase inactivation by Guiacol peroxide [21]. The Vitamin C content was determined using DNPH (Di Nitro Phenyl Hydrazine) method [22]. Iron content of the fresh and blanched leaves was determined using Atomic Absorption Spectrophotometer by Vogel method.

\section{Determination of phenolics, flavonoids and tannin contents}

Sample preparation for phenolic and flavonoids content. $0.5 \mathrm{~g}$ of each of the powdered tissues was weighed and extracted with $50 \mathrm{ml}$ $80 \%$ aqueous methanol for $2.5 \mathrm{~h}$ at room temperature with intermittent shaking. The extract was then centrifuged at 14,000 rpm for $5 \mathrm{~min}$ and the supernatant obtained was used for the assays.

\section{Total phenolics determination}

Total phenolics content was determined by the Folin-Ciocalteu colorimetric method [23] using gallic acid as a standard phenolic compound. $450 \mu \mathrm{l}$ of distilled water was added with $50 \mu \mathrm{l}$ of the extract and treated with $2.5 \mathrm{ml}$ of $0.3 \mathrm{~N}$ Folin-Ciocalteu reagent. After 5 min, $2 \mathrm{ml}$ of $7.5 \% \mathrm{Na}_{2} \mathrm{CO}_{3}$ solution was added and the mixture was incubated at $30^{\circ} \mathrm{C}$ for $1.5 \mathrm{~h}$ with intermittent shaking. The absorbance of the resulting blue colored solution was measured at $765 \mathrm{~nm}$ against blank. The evaluation was carried out, based on the six-point standard calibration curve of gallic acid $(20,100,200,300,400,500 \mathrm{mg} / \mathrm{L})$ in $80 \%$ aqueous methanol. The total phenolic content was expressed as gallic acid equivalents (GAE) in milligrams per gram of dry material.

\section{Total flavonoids determination}

Total flavonoids content was measured by the aluminum chloride colorimetric assay [24] using quercetin as a standard flavonoid. $1 \mathrm{ml}$ of the extract was added to $4 \mathrm{ml}$ of distilled water and $0.3 \mathrm{ml}$ of $5 \%$ $\mathrm{NaNO}_{2}$ and the mixture was incubated at room temperature for 5 min. After incubation, the mixture was treated with $0.3 \mathrm{ml} 10 \% \mathrm{AlCl}_{3}$ solution. After $1 \mathrm{~min}, 2 \mathrm{ml} 1 \mathrm{M} \mathrm{NaOH}$ was added and $2.4 \mathrm{ml}$ distilled water was added to the whole solution. The solution was mixed well and the absorbance was measured at $510 \mathrm{~nm}$ against blank. The assay was performed, based on the 6 point standard calibration curve of quercetin $(40,80,120,160,200,300 \mathrm{mg} / \mathrm{L})$ in $80 \%$ aqueous methanol. The total flavonoid content was expressed as quercetin equivalents (QE) in milligrams per gram of dry material.

\section{Tannin determination}

Tannin determination was carried out according to the method described by Van and Robinson [25] with minor modifications as described by Kaur and Arora [26] using tannic acid as standard. $50 \mathrm{ml}$ of distilled water was added to $250 \mathrm{mg}$ of powdered sample and shaken for $1 \mathrm{~h}$ using a mechanical shaker. It was filtered into a 50 -ml volumetric flask and the final volume was adjusted with distilled water. Then $1 \mathrm{ml}$ of the filtrate was added to $4 \mathrm{ml}$ of distilled water and treated with $2 \mathrm{ml}$ (10 fold diluted) of $0.1 \mathrm{M} \mathrm{FeCl}_{3}$ in $0.1 \mathrm{~N} \mathrm{HCl}$ and $0.008 \mathrm{M}$ potassium ferrocyanide. The solution was mixed well and the absorbance was measured at $605 \mathrm{~nm}$ within 10 min against blank. The evaluation was performed based on the 5 points standard calibration curve of tannic acid $(20,40,60,80,100,140,200 \mathrm{mg} / \mathrm{L})$ in distilled water. The tannin content was expressed as tannic acid equivalents (TAE) in milligrams per gram of dry material.

\section{Antioxidant activity determination by DPPH assay}

The free radical scavenging activity of methanolic extract was determined according to Liu et al. [27]. Briefly, the sample stock solutions $(1 \mathrm{mg} / \mathrm{ml})$ were diluted with methanol to final concentrations of $5,10,20,40,60,80,100$ and $200 \mu \mathrm{g} / \mathrm{ml} .2 \mathrm{ml}$ of each of the sample solution at different concentrations was mixed with $1 \mathrm{ml}$ of $0.25 \mathrm{mM}$ $\mathrm{DPPH}$ solution in methanol and allowed to react at room temperature in dark for $30 \mathrm{~min}$. The change in color was observed in terms of absorbance using a spectrophotometer at $517 \mathrm{~nm}$. And $1 \mathrm{ml}$ of methanol served as control. Quercetin was used as the standard antioxidant. The percentage of scavenging activity was calculated using the formula,

$\mathrm{DPPH}$ radical scavenging activity $(\%)=\left(\left(\mathrm{A}_{0}\right.\right.$ of control- $\mathrm{A}_{1}$ of sample)/ $\mathrm{A}_{0}$ of control) $\times 100$.

Where,

$A_{0}$ : Absorbance of the control

$A_{1}$ : Absorbance of the sample extract/ standard

Lower $\mathrm{IC}_{50}$ value indicated higher free radical scavenging activity.

\section{Determination of reducing power}

The reducing power of the extracts was determined according to the method of Oyaizu [28]. Different amounts of methanolic extracts $(100,200,300,400$ and $500 \mu \mathrm{g})$ in $1 \mathrm{ml}$ of methanol was mixed with $2.5 \mathrm{ml}$ of phosphate buffer $(0.2 \mathrm{M}, \mathrm{pH} 6.6)$ and $2.5 \mathrm{ml}$ of $1 \%$ potassium ferricyanide. The mixture was incubated at $50^{\circ} \mathrm{C}$ for $20 \mathrm{~min}$. After $2.5 \mathrm{ml}$ of $10 \%$ TCA were added, the mixture was centrifuged at 650 
rpm for $10 \mathrm{~min}$. The upper layer $(2.5 \mathrm{ml})$ solution was mixed with 2.5 $\mathrm{ml}$ distilled water and $0.5 \mathrm{ml}$ of $0.1 \% \mathrm{FeCl}_{3}$, and the absorbance was measured at $700 \mathrm{~nm}$. Increased absorbance of the reaction mixture indicated increased reducing power.

\section{Statistical analysis}

All the analyses were carried out in triplicate and expressed as mean standard deviation (SD). The calculation of means, $\mathrm{SD}, \mathrm{IC}_{50}$ values and analysis of variance (ANOVA) were carried out using Microsoft Office Excel 2007 and Duncan's multiple range tests (DMRT) were performed to study the differences at $5 \%$ level of significance among the phytochemical contents and antioxidant activities of the experimental leafy vegetables.

\section{Results and Discussion}

\section{Effect of blanching temperature on retention of vitamin $\mathrm{C}$}

The effects of blanching temperature on retention of vitamin $\mathrm{C}$ are shown in Table 1. Vitamin C content of all greens blanched at $80^{\circ} \mathrm{C}$ showed a reduction but the extent of loss varied between the vegetables. Retention was comparatively higher in Alternanthera sessilis (>50\%), moderate in Cardiospermum helicacabum (20\%) and lower in Celosia argentea (Table 1). The loss of Vitamin $\mathrm{C}$ in the leafy vegetables treated under identical temperature could be attributed to the fact that vitamin $\mathrm{C}$ is not stable at high temperature. With increase in temperature by another $10^{\circ} \mathrm{C}$, showed a further reduction of (1\%-10\%) in all the three samples. When the temperature of blanching in water was raised to $100^{\circ} \mathrm{C}$, Alternanthera sessilis and Cardiospermum helicacabum, which exhibited a higher retention of vitamin $\mathrm{C}$ at $80^{\circ} \mathrm{C}$ and $90^{\circ} \mathrm{C}$, reduced by another 3\%-5\% while in Celosia argentea it was marginal. Vitamin $\mathrm{C}$ is a highly soluble substance and thermal processing results in maximum losses [29]. Increase in temperature though reduced the Vitamin C content, the extent of difference between the samples treated with other temperature was not significant $(\mathrm{P}>0.05)$. These findings are in accordance to those reported by Gupta and Prakash [30] wherein they have shown that there is an increase in the loss of ascorbic acid in Amaranthus tricolor with every $10^{\circ} \mathrm{C}$ rise in the temperature of blanching media.

\section{Effect of blanching time and media on retention of Vitamin $\mathrm{C}$}

When the greens blanched at $80^{\circ} \mathrm{C}$ for $1 \mathrm{~min}$ in distilled water, Celosia argentea showed least retention (5\%-10\%) while Alternanthera sessilis and Cardiospermum helicacabum showed a moderate retention (20\%-30\%) of Vitamin C as shown in Table 2. With increase in blanching time for another $1 \mathrm{~min}$, Alternanthera sessilis and Celosia argentea showed a further loss of 5\%-10\% while in Cardiospermum helicacabum it was marginal. When the blanching time increased to $4 \mathrm{~min}$, Celosia argentea and Cardiospermum helicacabum showed a reduction of $10 \%$

\begin{tabular}{|c|c|c|c|c|}
\hline \multirow{4}{*}{ Leafy vegetables } & \multicolumn{4}{|c|}{ Vitamin C } \\
\hline & \multirow{3}{*}{$\mathrm{mg} / 100 \mathrm{~g}$} & \multicolumn{3}{|c|}{$\%$ retention } \\
\hline & & \multicolumn{3}{|c|}{ Blanched for 4 minutes in water } \\
\hline & & $80^{\circ} \mathrm{C}$ & $90^{\circ} \mathrm{C}$ & $100^{\circ} \mathrm{C}$ \\
\hline A. sessilis & 22.3 & 26.8 & 16.9 & 10.5 \\
\hline C. helicacabum & 44.6 & 22.7 & 14.0 & 11.9 \\
\hline C.argentea & 75.2 & 8.4 & 8.0 & 7.2 \\
\hline \multicolumn{5}{|c|}{ Statistical analysis } \\
\hline F- ratio & - & \multicolumn{3}{|c|}{$1.73^{\text {ns }}$} \\
\hline
\end{tabular}

Table 1: Effect of blanching temperature on the retention of Vitamin C (\%).

\begin{tabular}{|c|c|c|c|c|c|c|c|c|c|c|c|c|}
\hline \multirow{4}{*}{$\begin{array}{c}\text { Leafy } \\
\text { Veg- } \\
\text { etables }\end{array}$} & \multicolumn{12}{|c|}{ Blanched at $80^{\circ} \mathrm{C}$} \\
\hline & \multicolumn{12}{|c|}{ Time in minutes } \\
\hline & \multicolumn{3}{|c|}{ KMS } & \multicolumn{3}{|c|}{$\mathrm{NaCl}$} & \multicolumn{3}{|c|}{$\mathrm{NaHCO}_{3}$} & \multicolumn{3}{|c|}{ Water } \\
\hline & 1 & 2 & 4 & 1 & 2 & 4 & 1 & 2 & 4 & 1 & 2 & 4 \\
\hline $\begin{array}{l}\text { A. ses- } \\
\text { silis }\end{array}$ & 22.9 & 15.9 & 9.2 & 17.9 & 15.3 & 12.2 & 26.9 & 23.4 & 13.5 & 26.8 & 10.5 & 8.7 \\
\hline $\begin{array}{c}\text { C. heli- } \\
\text { cacabum }\end{array}$ & 32.9 & 14.5 & 11.6 & 40.9 & 34.6 & 17.3 & 45.3 & 32.8 & 15.3 & 22.7 & 11.7 & 7.0 \\
\hline $\begin{array}{c}\text { C. Ar- } \\
\text { gentea }\end{array}$ & 15.8 & 11.7 & 8.2 & 22.3 & 21.3 & 9.8 & 23.4 & 17.4 & 12.9 & 8.4 & 7.4 & 5.4 \\
\hline \multicolumn{13}{|c|}{ Statistical analysis } \\
\hline $\begin{array}{c}\text { Time } \\
\text { variant }\end{array}$ & \multicolumn{4}{|c|}{ KMS } & \multicolumn{2}{|c|}{$\mathrm{NaCl}$} & \multicolumn{2}{|c|}{$\mathrm{NaHCO}_{3}$} & \multicolumn{4}{|c|}{ Water } \\
\hline F-ratio & \multicolumn{4}{|c|}{$5.84^{*}$} & \multicolumn{2}{|c|}{$1.82^{\mathrm{ns}}$} & \multicolumn{2}{|c|}{$3.66^{\text {ns }}$} & \multicolumn{4}{|c|}{$3.67^{\mathrm{ns}}$} \\
\hline \multicolumn{13}{|c|}{ Time vs Media } \\
\hline \multicolumn{6}{|c|}{ Time in min. } & \multicolumn{7}{|c|}{ F-ratio } \\
\hline \multicolumn{6}{|c|}{1} & \multicolumn{7}{|c|}{$0.73^{\text {ns }}$} \\
\hline \multicolumn{6}{|c|}{2} & \multicolumn{7}{|c|}{$3.76^{*}$} \\
\hline \multicolumn{6}{|c|}{4} & \multicolumn{7}{|c|}{$5.50^{\star}$} \\
\hline
\end{tabular}

Table 2: Effect of blanching media and time on the retention of Vitamin C (\%).

and $20 \%$, respectively in comparison with the samples blanched for 2 min. Analysis of variance revealed that increasing the blanching time by $1-2$ min at same temperature is not significantly affect the losses of nutrients $(\mathrm{P}>0.05)$.

The blanched leafy vegetables in KMS solution at $80^{\circ} \mathrm{C}$ for $1 \mathrm{~min}$ showed better retention of vitamin $\mathrm{C}$ where in other media, salt and sodium carbonate showed a least retention. The results shown in Table 2 with increase in blanching time to $4 \mathrm{~min}$, Alternanthera sessilis and Cardiospermum helicacabum showed a further loss of $10 \%$ while in Celosia argentea the losses were remarkable. No significant losses were encountered with increase in the blanching time by $1-2 \mathrm{~min}$ at the same temperature in potassium metabisulphite. The GLV of blanched at $80^{\circ} \mathrm{C}$ for $1 \mathrm{~min}$ in $\mathrm{KMS}$ had $10 \%-15 \%$ higher retention of ascorbic acid compared to other media. Even with increase in blanching time by 1-2 min, potassium metabisulphite blanched greens showed statistically significantly $(\mathrm{P}<0.05)$ retention over other blanching media. Similar observations were reported for fenugreek leaves and other vegetables [31]. These findings infer that blanching media offer a protection against oxidation of vitamin $\mathrm{C}$ and thereby a higher retention of the water-soluble vitamin was observed.

\section{Effect of blanching on nutritional content of green leafy vegetables}

The values obtained for nutrient content of green leafy vegetables were higher than the values reported by Narasingha et al. [32]. Moisture content of blanched leaves is $70 \%$ for Alternanthera sessilis, $82.7 \%$ for Cardiospermum helicacabum and $83.4 \%$ for Celosia argentea (Table 3). Reduction in the moisture content on blanching was found to be statistically significant $(\mathrm{P}<0.05)$. Nkafamiya et al. [33] reported that the moisture content was lower in blanched sample of some vegetable. However, the high moisture content indicates short shelf life and high vulnerability to microbial attack.

The protein content of fresh and blanched GLV was found to be similar. The slight variations that observed were found to be statistically insignificant $(\mathrm{P}>0.05)$. This agrees with the findings of Sobowale et al. [34]. In fresh samples the fiber was found to be in the range of 0.2-2.7 $\mathrm{g}$ (fresh weight basis). Blanching caused significantly higher $(\mathrm{P}<0.01)$ reductions in the fiber content. According to Punna and Rao [35] no 
significant effect of processing /cooking on insoluble dietary fiber content of green leafy vegetables. Among the fresh GLV, Celosia argentea had the maximum amount of iron, whereas Alternanthera sessilis and Cardiospermum helicacabum had the least. Blanched Celosia argentea had $22.5 \mathrm{mg} / 100 \mathrm{~g}$ whereas Alternanthera sessilis and Cardiospermum helicacabum had $1.96 \mathrm{mg} / 100 \mathrm{~g}$ and $1.88 \mathrm{mg} / 100 \mathrm{~g}$. The results (Table 3) indicate that blanching caused significantly higher $(\mathrm{P}<0.01)$ reductions in the Iron content of Green Leafy Vegetables. Oladunmoye et al. [36] were observed similarly that reduction in iron content of blanched and cooked tender and mustard cassava leaves.

\section{Phenolics, flavonoids and tannin content determination}

Phenolics are aromatic secondary plant metabolites widely spread throughout the plant kingdom. The antioxidant activity of phenolic compounds is mainly due to redox properties, which allow them to act as reducing agents, hydrogen donors, singlet oxygen quenchers, heavy metal chelators and hydroxyl radical quenchers [37]. The phenolic compounds evolved to protect the plants from herbivores. It has been reported that by acting as antioxidants the phenolics counteract the photo damage and their level varies with the extent of exposure [38]. The correlation between the phenolic content and the observed antioxidant activity of a particular plant species are evident from a number of publications [39,40]. Shahidi et al. [41] reported different classes of phenolics possessing varying antioxidative strengths and the synergistic effect of polyphenolics (flavonoids, condensed tannins and gallotannins) in the observed antioxidant activity. Flavonoids constitute majority of the polyphenolic compounds and include anthocyanins, proanthocyanins, flavonols and catechins [42]. Flavonoids act by scavenging or chelating [43]. All these compounds found in plants therefore have great beneficial effects on human health. This study was initiated to investigate these potential sources of natural antioxidants in leafy vegetables that are consumed in many parts of India. The total phenol content of GLV is presented in Table 4. The GLV were found to have varying levels of phenol, ranging $C$. argentea 3.89 to 8.55 for A. sessilis. Kaur and Kapoor [44] reported the total phenolic content of Trigonella foenumgraecum to be $217.5 \mathrm{mg}$ of

\begin{tabular}{|c|c|c|c|c|}
\hline $\begin{array}{c}\text { GLVI } \\
\text { Nutrient }\end{array}$ & A.sessilis & C.helicacabum & C. argentea & F-ratio \\
\hline \multicolumn{5}{|c|}{ Moisture (\%) } \\
\hline Fresh & 75 & 84 & 85 & \multirow{2}{*}{$17.12^{*}$} \\
\hline Blanched & 70.2 & 82.7 & 83 & \\
\hline \multicolumn{5}{|c|}{ Protein (g) } \\
\hline Fresh & 5.6 & 4.2 & 3.8 & \multirow{2}{*}{$0.68^{\mathrm{ns}}$} \\
\hline Blanched & 3.5 & 3.9 & 3.2 & \\
\hline \multicolumn{5}{|c|}{ Fiber (g) } \\
\hline Fresh & 2.7 & 0.2 & 2.4 & \multirow{2}{*}{$54.5^{\star}$} \\
\hline Blanched & 2.4 & - & 1.9 & \\
\hline \multicolumn{5}{|c|}{ Iron $(\mathrm{mg} / 100 \mathrm{~g})$} \\
\hline Fresh & 1.93 & 2.03 & 24.6 & \multirow{2}{*}{$422.4^{*}$} \\
\hline Blanched & 1.88 & 1.96 & 22.5 & \\
\hline
\end{tabular}

Table 3: Effect of blanching on nutritional content of green leafy vegetables. catechol/100 g of fresh vegetable. Salvatore et al. [37] in their study on antioxidant characterization of some Sicilian edible greens stated that the frequently consumed greens in the Mediterranean areas were very rich in antioxidants such as flavonoids and carotenoids. The total polyphenol content of some common Indian leafy vegetables was found to be in the range of $5 \mathrm{mg}-69.5 \mathrm{mg}$ of tannic acid/g of extract [45]. Therefore, it can be said that the total polyphenol content of vegetables varies widely depending on the variety of vegetable and a comparison is difficult, as different standard compounds have been used for their analysis. Our results were revealed that highly significant differences in the total phenol content of the GLV analyzed.

\section{DPPH radical scavenging activity}

DPPH is a stable free radical and accepts an electron or hydrogen radical to become a stable diamagnetic molecule. The methodology involves reaction of specific compounds or extracts with DPPH in methanol solution. In the presence of hydrogen donors, DPPH is reduced and a free radical is formed from the scavenger. The reaction of DPPH is monitored by the decrease of the absorbance of its radical at $517 \mathrm{~nm}$, but upon reduction by an antioxidant, the absorption disappears [46]. Exponential increase of antioxidant activity due to the development of the reducing power signifies that the antioxidant properties are associated with the development of reducing power $[46,47]$. DPPH radical scavenging activity of the GLV extracts at varying concentrations $(6.37-18.42 \mathrm{mg} / \mathrm{ml})$ were measured and the results are depicted in Table 5. All the GLV studied showed appreciable free radical scavenging activities. Of the three leafy vegetable extracts tested, extracts of $A$. sessilis had the strongest radical scavenging activity compared to the other GLV (83.44\%). A. sessilis has been found to exhibit the most potent DPPH scavenging activity followed by $C$. helicacabum. The $\mathrm{IC}_{50}$ value of $C$. argentea, A. sessilis and C. helicacabum is $760.34,653.10$ and $590.54 \mu \mathrm{g} / \mathrm{ml}$, respectively. The strong DPPH radical scavenging activity of $E$. fluctuans is in line with earlier studies by Dasgupta and De [48]. The $\mathrm{IC}_{50}$ value of the reference compound quercetin has been found to be $3.65 \mu \mathrm{g} / \mathrm{ml}$ and has exhibited higher activity than all the leafy vegetables extracts tested. ANOVA analysis has shown the presence of highly significant differences in the free radical scavenging activity of the different species of leafy vegetables studied $(\mathrm{P}=0.000)$. Use of purified antioxidative compounds of phenolic origin from the plant species with potent antioxidant activities might exhibit better activity than observed with crude extracts. Phenolic compounds isolated from the genus Corchorus have been reported to possess significant antioxidant activity in the linoleic acid peroxidation system [49].

\section{Reducing power determination}

The antioxidant effect exponentially increases as a function of the development of the reducing power, indicating that the antioxidant properties are concomitant with the development of reducing power [28]. Reducing power of tannins from medicinal plants prevents liver injury by inhibiting formation of lipid peroxides [50]. The antioxidant and reducing capacity of spices is closely related to the presence of chemical constituents with antioxidant activity, mainly to the phenolic

\begin{tabular}{|c|c|c|c|}
\hline Leafy Vegetables & $\begin{array}{c}\text { Total phenolics } \\
\text { (mg GAE/g dry weight) }\end{array}$ & $\begin{array}{c}\text { Total flavonoids } \\
\text { (mg QE/g dry weight) }\end{array}$ & $\begin{array}{c}\text { Total tannin } \\
\text { (mg TAE/g dry weight) }\end{array}$ \\
\hline A.sessilis & $8.55 \pm 0.08$ & $9.47 \pm 1.03$ & $13.58 \pm 0.75$ \\
\hline C. helicacabum & $7.89 \pm 0.29$ & $37.66 \pm 2.04$ & $10.47 \pm 0.15$ \\
\hline C. argentea & $3.89 \pm 0.13$ & $17.54 \pm 2.74$ \\
\hline
\end{tabular}

Each value is the mean \pm standard deviation from three replicates 
Citation: Saranya R, Devanesan G, Ramesh S, Gopi R (2017) Effect of Processing on Nutritional Quality and Antioxidant Potentials of Leafy Vegetables. J Food Process Technol 8: 694. doi: 10.4172/2157-7110.1000694

Page 5 of 6

\begin{tabular}{|c|c|c|c|c|c|c|c|c|c|}
\hline \multicolumn{10}{|c|}{ DPPH radical scavenging activity $(\%)^{\mathrm{a}}$} \\
\hline $\begin{array}{c}\text { Leafy } \\
\text { Vegetables }\end{array}$ & $5 \mu \mathrm{g} / \mathrm{mL}$ & $10 \mu \mathrm{g} / \mathrm{mL}$ & $20 \mu \mathrm{g} / \mathrm{mL}$ & $40 \mu \mathrm{g} / \mathrm{mL}$ & $60 \mu \mathrm{g} / \mathrm{mL}$ & $80 \mu \mathrm{g} / \mathrm{mL}$ & $100 \mu \mathrm{g} / \mathrm{mL}$ & $200 \mu \mathrm{g} / \mathrm{mL}$ & $\mathrm{IC}_{50} \mu \mathrm{g} / \mathrm{mL}$ \\
\hline A. sessilis & $6.57 \pm 1.15$ & $8.35 \pm 0.24$ & $8.64 \pm 0.13$ & $9.39 \pm 0.16$ & $10.90 \pm 0.78$ & $12.22 \pm 1.16$ & $12.74 \pm 0.68$ & $18.42 \pm 1.10$ & 653.10 \\
\hline C. helicacabum & $6.75 \pm 1.46$ & $7.56 \pm 1.62$ & $8.38 \pm 2.36$ & $9.63 \pm 1.51$ & $10.67 \pm 0.08$ & $11.80 \pm 0.46$ & $13.72 \pm 0.41$ & $22.15 \pm 0.76$ & 590.54 \\
\hline C. argentea & $6.37 \pm 0.97$ & $6.45 \pm 0.86$ & $6.53 \pm 0.69$ & $7.60 \pm 0.40$ & $8.65 \pm 1.00$ & $9.55 \pm 1.06$ & $11.46 \pm 1.22$ & $15.21 \pm 1.26$ & 760.34 \\
\hline- & $0.5 \mu \mathrm{g} / \mathrm{mL}$ & $1 \mu \mathrm{g} / \mathrm{mL}$ & $2 \mu \mathrm{g} / \mathrm{mL}$ & $3 \mu \mathrm{g} / \mathrm{mL}$ & $4 \mu \mathrm{g} / \mathrm{mL}$ & $5 \mu \mathrm{g} / \mathrm{mL}$ & $6 \mu \mathrm{g} / \mathrm{mL}$ & & \\
\hline Quercetin & $8.68 \pm 1.40$ & $14.21 \pm 1.48$ & $23.50 \pm 1.38$ & $38.47 \pm 1.23$ & $51.44 \pm 1.22$ & $83.41 \pm 1.00$ & $67.65 \pm 0.68$ & $86.40 \pm 0.21$ & 3.65 \\
\hline
\end{tabular}

${ }^{a}$ Each value is the mean \pm standard deviation from three replicates

Table 5: In vitro free radical scavenging activity by DPPH method.

\begin{tabular}{|c|c|c|c|c|c|}
\hline \multicolumn{6}{|c|}{ Reducing power assay (absorbance) ${ }^{a}$} \\
\hline Plants & $100 \mu \mathrm{g} / \mathrm{mL}$ & $200 \mu \mathrm{g} / \mathrm{mL}$ & $300 \mu \mathrm{g} / \mathrm{mL}$ & $400 \mu \mathrm{g} / \mathrm{mL}$ & $500 \mu \mathrm{g} / \mathrm{mL}$ \\
\hline A. sessilis & $\begin{array}{c}0.013 \pm \\
0.001\end{array}$ & $\begin{array}{l}0.037 \pm \\
0.004\end{array}$ & $\begin{array}{c}0.070 \pm \\
0.016\end{array}$ & $\begin{array}{c}0.085 \pm \\
0.019\end{array}$ & $\begin{array}{c}0.096 \pm \\
0.003\end{array}$ \\
\hline $\begin{array}{c}\text { C. } \\
\text { helicacabum }\end{array}$ & $\begin{array}{l}0.040 \pm \\
0.005\end{array}$ & $\begin{array}{c}0.089 \pm \\
0.006\end{array}$ & $\begin{array}{c}0.121 \pm \\
0.002\end{array}$ & $\begin{array}{c}0.149 \pm \\
0.005\end{array}$ & $\begin{array}{c}0.190 \pm \\
0.004\end{array}$ \\
\hline C. argentea & $\begin{array}{c}0.018 \pm \\
0.002\end{array}$ & $\begin{array}{c}0.055 \pm \\
0.009\end{array}$ & $\begin{array}{c}0.069 \pm \\
0.002\end{array}$ & $\begin{array}{c}0.087 \pm \\
0.001\end{array}$ & $\begin{array}{c}0.106 \pm \\
0.002\end{array}$ \\
\hline - & $5 \mu \mathrm{g} / \mathrm{mL}$ & $25 \mu \mathrm{g} / \mathrm{mL}$ & $50 \mu \mathrm{g} / \mathrm{mL}$ & $75 \mu \mathrm{g} / \mathrm{mL}$ & $100 \mu \mathrm{g} / \mathrm{mL}$ \\
\hline Quercetin & $\begin{array}{c}0.078 \pm \\
0.020\end{array}$ & $\begin{array}{c}0.288 \pm \\
0.016\end{array}$ & $\begin{array}{c}0.514 \pm \\
0.029\end{array}$ & $\begin{array}{c}0.724 \pm \\
0.039\end{array}$ & $\begin{array}{c}0.908 \pm \\
0.028\end{array}$ \\
\hline
\end{tabular}

Table 6: In vitro antioxidative activity by reducing power determination.

compounds [51-54]. The antioxidant capacities were in the order of A.sessilis $>$ C.helicacabum $>$ C.argentea (Table 6). There are very few studies on the antioxidant capacity of vegetable measured by the phosphomolybdenum method. Dasgupta and De [48] studied the antioxidant capacity of three varieties of Piper betle leaves and reported that the Kauri variety had higher total antioxidant capacity (equivalents of gallic acid) in comparison with tea. The activity of the reference compound quercetin is higher than the experimental leafy vegetables. ANOVA analysis $(\mathrm{P}=0.000)$ has suggested the presence of significant differences in the reducing power of these leafy vegetables.

\section{Conclusion}

In the present study, all of the three leafy vegetables Alternanthera sessilis, Cardiospermum helicacabum and Celosia argentea have been found Vitamin $\mathrm{C}$ was sensitive to heat and oxidation during blanching. Among the plants selected, Alternanthera sessilis had a better retention of Vitamin C followed by Cardiospermum helicacabum and Celosia argentea. Potassium metabisulphite showed better retention of vitamin $\mathrm{C}$ followed by sodium bicarbonate and sodium chloride. Blanching at $80^{\circ} \mathrm{C}$ for $1 \mathrm{~min}$ ensured peroxidase inactivation in all greens. The losses of nutritional content protein, moisture, fiber and iron were marginal. But Vitamin $\mathrm{C}$ which is a major antioxidant known for proper functioning of the human body had a better retention during blanching. Thus, it can be suggested that blanching at $80^{\circ} \mathrm{C}$ for $1 \mathrm{~min}$ in Potassium metabisulphite are the most ideal for blanching greens. These GLVs have been found to possess minor to major DPPH radical scavenging activities. Of all the leafy vegetables tested, A. sessilis, C. helicacabum and C. argentea possess the maximum activity with regard to the antioxidative potential. Pertaining to the stability of antioxidative activity of leafy vegetables at higher temperatures suggests that the consumption of leafy vegetables in daily diet either in raw or in cooked form can be a good source of natural antioxidants, beneficial for health. Therefore, the leafy vegetables can be potential sources of natural antioxidants for domestic consumption as well as possible substitutes for synthetic antioxidants for industrial purpose. These above study results may serve as a guide to select blanching temperature, time and media for processing the vegetables. In conclusion, these findings may be useful for the selection of spices for further application in different food formulations to support their function as antioxidants. Statistical package was found to be an effective tool for analysis of variance.

\section{References}

1. Rajeswari R, Pushp Abhara T, Ramachandra NK, Shobhanaganur A (2013) Dehydration of Amaranthus leaves and its quality evaluation. Karnataka J Agri Sci 26: 276-280

2. Salah N, Millar NJ, Paganga G, Tijburg L, Bolwell GPR, et al. (1995) Polyphenolic flavanols as scavengers of aqueous phase radicals and as chainbreaking antioxidants. Arch Biochem Biophy 322: 339-346.

3. Van Acker SA, Van Den BE, Vijgh WJF, Bast F (1996) Structural aspects of antioxidant activity of flavonoids. Free Rad Bio Med 20: 331-342.

4. Waladkhani A, Clemens MR (1998) Effect of dietary phytochemicals on cancer development. Inter J Mol Med 1: 747-757.

5. Aruoma OI (1998) Free radicals, oxidative stress and antioxidants in human health and disease. J Ame Oil Chem Soc 75: 199-212.

6. Oboh G (2005) Effect of blanching on the antioxidant properties of some tropical green leafy vegetables. LWT. Food Sci Tech 38: 513-517.

7. Tarwadi K, Agte V (2005) Antioxidant and micronutrient quality of fruit and root vegetables from the Indian subcontinent and their comparative performance with green leafy vegetables and fruits. J Sci Food Agri 85: 469-1476.

8. Ames BN (1983) Dietary carcinogens and anticarcinogens: Oxygen radicals and degenerative diseases. Sci 22: 1256-1264.

9. Stadtman ER (1992) Protein oxidation and aging. Sci 257: 1220-1224

10. Tawaha K, Alali FQ, Gharaibeh M, Mohammad M, El-Elimat T (2007)Antioxidant activity and total phenolic content of selected Jordanian plant species. Food Chem 104: 1372-1378.

11. Satwase AN, Pandhre GR, Sirsat PG and Wade YR (2013) Studies on drying characteristic and nutritional composition of drumstick leaves by using sun shadow, cabinet and oven drying methods. Ope Acc Sci Rep 2: 1-4.

12. Akindahunsi AA, Oboh G (1999) Effect of some post-harvest treatments on the bioavailability of zinc from some selected tropical vegetables. La Riv Ital Delle Sost Gra 125: 285-287.

13. Negi PS, Roy SK (2000) Effect of blanching and drying methods on $\beta$-carotene ascorbic acid and chlorophyll retention of leafy vegetables. Leb Wiss Tech 33: 295-298.

14. Kadam DM, Samuel DVK, Chandra P, Sirkarwar HS (2008) Impact of processing treatments and packaging materials on some properties of stored dehydrated cauliflower. Inter J Food Sci Tech 43: 1-14.

15. Selman JD (1994) Vitamin retention during blanching of vegetables. Food Chem 49: 137-147.

16. Barret DM, Theerakulkait C (1995) Quality indicators in blanched, frozen, stored vegetables. Food Tech 49: 62-65.

17. Muftugil N (1985) The peroxidase enzyme activity of some vegetables and its resistance to heat. J Sci Food Agri 36: 877-880.

18. AOAC (2000) Official methods of analysis. Asso Offi Anal Chem, Arlington, VA

19. Lowry OH, Rosebrough NJ, Farr NJ, Randall RJ (1951) Protein measurement with the folin phenol reagent. J Biol Chem 193: 265-275. 
Citation: Saranya R, Devanesan G , Ramesh S, Gopi R (2017) Effect of Processing on Nutritional Quality and Antioxidant Potentials of Leafy Vegetables. J Food Process Technol 8: 694. doi: 10.4172/2157-7110.1000694

20. AOAC (1990) Official methods of analysis. Asso Offi Anal chem, Arlington, VA.

21. Masure MP, Campbell H (1994) Rapid estimation of peroxidase in vegetable extracts- an index of blanching adequacy for frozen vegetables. Fruit Pro J Am Food Manu 23: 369-374.

22. Rehman KMM, Rehman MM, Islam MS, Begum SA (2006) A simple UVSpectrophotometric method for the determination of vitamin $C$ content in various fruits and vegetables at sylhet area in Bangladesh. J Bio Sci 6: 388-392.

23. Singleton VL, Rossi JA (1965) Colorimetry of total phenolics with phosphomolybdic phosphotungstic acid reagents. Ame J Enol Vitic 16: 144-158.

24. Zhishen J, Mengcheng T, Jianming W (1999) The determination of flavonoid contents in mulberry and their scavenging effects on superoxide radicals. Food Chem 64: 555-559.

25. Van BJP, Robinson WB (1969) Formation of complexes between protein and tannic acid. J Agri Food Chem 17: 772-777.

26. Kaur GJ, Arora DS (2009) Antibacterial and phytochemical screening of A graveolens, F vulgare and T ammi. BMC Comp Alt Med 9: 30-39.

27. Liu X, Zhao M, Wang J, Yang B, Jiang Y (2008) Antioxidant activity of methanolic extract of emblica fruit (P. emblica L.) from six regions in China. J Food Comp Anal 21: 219-228.

28. Oyaizu M (1986) Studies on product of browning reaction prepared from glucose amine. Jap J Nut 44: 307-315

29. Arroqui C, Rumsey TR, Lopez A, Virseda P (2001) Effect of different soluble solids in the water on the ascorbic acid losses during water blanching of potato tissue. J Food Engg 47: 123-126.

30. Gupta S, Prakash J (2008) Effect of different blanching treatments on ascorbic acid retention in green leafy vegetables. Nat Prod Radi 7: 111-116.

31. Patil VR, Kulkarni DN, Kulkarni K, Ingle UM (1978) Effect of blanching factors on quality of sun dried and dehydrated fenugreek (methi). Indian Food Packer 32: 43-47.

32. Narasingha BS Rao, Deosthale YG, Pant KC (1989) Nutritive value of Indian foods. National Institute of Nutrition, Hyderabad, India.

33. Nkafamiya II, Oseameahon SA, Modibbo UU, Haggai D (2010) Vitamins and effect of blanching on nutritional and antinutritional values of non-conventional leafy vegetables. Afri J Food Sci 4: 335-341

34. Sobowale SS, Olatidoye OP, Olorode OO, Sokeye OK (2010) Effect of preservation methods and storage on nutritional quality and sensory properties leafy vegetables consumed in Nigeria. J Med App Bio 2: 46-56.

35. Punna R, Rao UP (2004) Effect of maturity and processing on total, insoluble and soluble dietary fiber contents of Indian green leafy vegetables. Inter J Food Sci Nut 55: 561-567.

36. Oladunmoye OO, Ojeniyi S, Bankole AO (2005) Mineral composition of tende and mustard cassava leaves after home cooking procedures. Nigeria Inst Food Sci Tech Abakaliki pp. 137-139.

37. Salvatore S, Pellegrini N, Brenna OV, Del RD, Frasca G, et al. (2005) Antioxidant characterization of some Sicilian edible wild greens. J Agri Food Chem 53: 9465-9471.
38. Close DC, Mc Arthur C (2002) Rethinking the role of many plant phenolicsprotection from photo damage not herbivores? Oikos 99: 166-172.

39. Banerjee D, Chakrabarti S, Hazra AK, Banerjee S, Ray J, et al. (2008) Antioxidant activity and total phenolics of some mangroves in Sundarbans. Afr J Biote 7: 805-810.

40. Aritra S, Kashinath C, Amit R (2014) A comparative study on antioxidant potentials of some leafy vegetables consumed widely in India. J Food Biochem 38: 365-373.

41. Shahidi F,Wanasundara UN Amarowicz R (1994) Natural antioxidants from low pungency mustard floor. Food Res Int 27: 489-493.

42. Mervat ME, Hanan AT (2009) Antioxidant activities, total anthocyanins, phenolics and flavonoids contents of some sweet potato genotypes under stress of different concentrations of sucrose and sorbitol. Aust J Basic Appl Sci 3: 3609-3616.

43. Cook NC, Sammam S (1996) Flavonoids-chemistry metabolism, cardioprotective effects and dietary sources. J Nut Biochem 7: 66-76.

44. Kaur C, Kapoor HC (2002) Anti-oxidant activity and total phenolic content of some Asian vegetables. Inter J Food Sci Tech 37: 153-161.

45. Shyamala BN, Gupta S, Lakshmi AJ, Prakash J (2005) Leafy vegetable extracts-antioxidant activity and effect on storage stability of heated oils. Innov Food Sci Emerg Tech 6: 239-245.

46. Brand WW, Cuvelier ME, Berset C (1995) Use of a free radical method to evaluate antioxidant activity. LWT Food Sci Tech 28: 25-30.

47. Gopi R, Kavina J, Divya VN, MohanKumar M, Alagu Lakshmanan GM, et al (2011) Anti-oxygen radical potential of leafy vegetables a comparative study. J Pha Res 4: 4.

48. Dasgupta N, De B (2007) Antioxidant activity of Piper betle L. leaf extract in vitro. Food Chem 88: 219-224.

49. Azuma K, Nakayama M, Koshioka M, Ippoushi K, Yamaguchi Y, et al. (1999) Phenolic antioxidants from the leaves of C.olitorius L. J Agri Food Chem 47: 3963-3966.

50. Okuda T, Kimura Y, Yoshida T, Hatano T, Okuda H, et al. (1983) Studies on the activity and related compounds from medicinal plants and drugs: I. Inhibitory effects on lipid peroxidation on mitochondria and microsomes of liver. Chem Pharm Bull 31: 1625-1631.

51. Parthasarathy VA, Chempakam B, Zachariah TJ (2008) Chemistry of spices. CABI, Oxfordshire, UK.

52. Peter KV (2001) Handbook of herbs and spices. Woodhead Publishing Limited, Cambridge, UK.

53. Peter KV (2004) Handbook of herbs and spices ( $2^{\text {nd }}$ Volume). Woodhead Publishing Limited, Cambridge, UK.

54. Steinhaus $M$, Schieberle $P$ (2005) Characterization of odorants causing an atypical aroma in white pepper powder (Piper nigrum L.) based on quantitative measurements and orthonasal breakthrough thresholds. J Agri Food Chem 53 : 6049-6055. 